\title{
Lodgepole Pine and White Spruce Crown Fuel Weights Predicted from Diameter at Breast Height
}

\author{
by Allen F. Johnson ${ }^{1}$, Paul M. Woodard, and Stephen J. Titus
}

\begin{abstract}
Regression equations that predict the foliage and roundwood biomass by diameter classes: $0.0-0.5 \mathrm{~cm}, 0.5-1.0 \mathrm{~cm}$, $1.0-3.0 \mathrm{~cm}, 3.0-5.0 \mathrm{~cm}, 5.0-7.0 \mathrm{~cm}$ and $7.0-10.0 \mathrm{~cm}$ given diameter at breast height ( $\mathrm{dbh}$ ) were developed for lodgepole pine and white spruce. Common to the Prairie Provinces the allometric model $y=a \mathrm{dbh}^{\mathrm{b}}$ fit the data well for all component categories except the roundwood classes $>3.0 \mathrm{~cm}$. The $r^{2}$ values generally exceed .80 and SEE were small. The larger size classes are best predicted by multiplying the number of trees affected by a constant. The management value of this new information is significant when viewed from an ecologic perspective.
\end{abstract}

\section{Résumé}

Les équations de régression qui prédisent la biomasse du feuillage et de la matière ligneuse brute par classes de diamètre de 0.0 à $0.5 \mathrm{~cm}$, de 0.5 à $1.0 \mathrm{~cm}$, de 1.0 à $3.0 \mathrm{~cm}$, de 3.0 à $5.0 \mathrm{~cm}$, de 5.0 à $7.0 \mathrm{~cm}$ et de 7.0 à $10.0 \mathrm{~cm}$ selon un diamètre donné à hauteur de poitrine (dhp) ont été développées pour le pin lodgepole et l'épinette blanche. Applicable dans les provinces des prairies, le modèle allométrique $y=a \mathrm{dhp}^{\mathrm{b}}$ correspond bien aux données pour toutes les catégories de composantes à l'exception des classes de matière ligneuse brute supérieure à $3.0 \mathrm{~cm}$. Les valeurs de $r^{2}$ excèdent habituellement .80 et les écarts types sont faibles. Les classes de diamètre plus importantes sont mieux prédites en multipliant le nombre d'arbres affectés par une constante. La valeur en aménagement de cette nouvelle information est significative lorsqu'étudiée selon une perspective écologique.

\section{Introduction}

Standing live biomass is recognized as an important potential fuel source in many forest stands (Brown 1976, Stocks 1980). Equations or tables are available to predict standing biomass for most tree species in Alberta (Kiil 1967, 1968; Stanek and State 1978; Johnstone and Peterson 1980; Singh 1986; Delisle 1986). Except for Woodard and Delisle (1987), most of these authors have not attempted to predict fuel weights by the roundwood diameter classes now desired by forest fire agencies in Canada, and the Woodard and Delisle equations only pertain to juvenile trees $\leq 3 \mathrm{~m}$ in height. Therefore, the objective of this study was to develop equations that would predict: the total crown fuel weight, live crown fuel weight, foliage weight, or individual roundwood diameter class fuel weights for mature lodgepole pine (Pinus contorta Loudon var. latifolia Engelm.) and white spruce (Picea glauca (Moench) Voss var. albertiana (S. Brown) Sarg. $)^{2}$ Diameter at breast height (dbh) was chosen as the independent variable because this characteristic is known to be highly correlated to tree weight (Stanek and State 1978). Also, it is easily and accurately measured in the field, and it is a variable consistently sampled in many forest inventories.

\section{Study Area and Methods}

Sampling occurred within the "Mixedwood Section" and the "Foothills Section" of the Boreal Forest Region, and within the Subalpine Forest Region (Rowe 1972). The number of trees sample by species and locations are shown

Department of Forest Science, University of Alberta, Edmonton, Alberta T6G 2H1.

'Current address: National Indian Inst., Box 2138, Meadow Lake, Sask. SOM IV0.

Address all correspondence to: Dr. P.M. Woodard, 855 General Services Bldg., Department of Forest Science, University of Alberta, Edmonton, Alberta, T6G 2H1, Canada. (Phone: 403-493-3314).

${ }^{2}$ Moss (1983) is the botanical authority for this work. in Figure 1. The ecological conditions for the ecoregions where sampling was conducted have been described by Strong and Leggat (1981) or more generally by Rowe (1972).

Sample trees were selected from representative stands found on "good" sites (site index $\geq 18 \mathrm{~m}$ at reference age 50 years at breast height). All trees selected were dominant or codominant in crown position and appeared to be uniform in crown shape. None were open grown or showed visible signs of deformity. Only one or two trees were selected from within any one stand. The selection criteria used for this project are comparable to previous studies (Brown 1976).

The diameter at breast height $(\mathrm{dbh} \pm 0.1 \mathrm{~cm})$ was measured on each tree prior to felling. Sample trees less than $15 \mathrm{~cm}$ dbh were felled directly onto tarps, then delimbed. Larger trees were climbed and delimbed to a $10-\mathrm{cm}$ top before felling (Brown 1976). Beginning at the base of the sample tree, all live and dead branches were cut using a hand saw. Every fourth branch in sequence was then placed on a separate tarp for further analysis. This subsample of both dead (not supporting live foliage) and live (supporting live foliage) roundwood was then separated into the following roundwood (branch and bole) diameter classes: $0.0-0.5 \mathrm{~cm}$, $0.5-1.0 \mathrm{~cm}, 1.0-3.0 \mathrm{~cm}, 3.0-5.0$ and $5.0-7.0 \mathrm{~cm}$ (Van Wagner 1982). In addition, roundwood between 7.0 and $10.0 \mathrm{~cm}$ diameter was also weighed. Both the stratified and remaining unstratified sample of roundwood was weighed $( \pm 0.1 \mathrm{~kg})$ using a portable spring scale. Oven-dried weights $( \pm 0.1 \mathrm{~g})$ of all fresh material was determined by thermogravimetric methods at $70^{\circ} \mathrm{C}$.

The allometric model $\left(Y=a X^{b}\right)$, where $X$ is the diameter at breast height was used to describe the relationship between total tree crown or the crown component weight and dbh functions (Baskerville 1972). An empirical $r^{2}$ value [1-(SSresidual/SStotal)], was calculated to indirectly measure the "quality" of each non-linear equation. The 




Figure 1. Location and number of pine $(\mathrm{P})$ and spruce $(\mathrm{S})$ trees sampled in Alberta, Canada.

standard error of the estimate and a residuals plot were used as direct measures.

\section{Results}

A total of 27 lodgepole pine trees ranging from $7 \mathrm{~cm}$ to $48 \mathrm{~cm}$ at $\mathrm{dbh}$; and 23 white spruces between 8 and $63 \mathrm{~cm}$ in dbh were selected, processed and analyzed. For both species, dbh was high correlated to total crown weight, live crown weight, foliage weight and the weight of any roundwood fuel diameter class. There was poor correlation between dbh and the weight of the dead roundwood. Total crown weight is a composite weight of all biomass found in a tree, even dead branches and tops $<10 \mathrm{~cm}$. The live crown weight does not include dead plant tissue. The curvilinear allometric model $\left(Y=a \mathrm{dbh}^{b}\right)$ fit the data well for all component categories except the roundwood diameter classes $>3.0 \mathrm{~cm}$. The coefficients $(a, b)$, the $r^{2}$ value, the standard error of the estimate (SEE), the predicted mean $(Y)$ and the SEE as a percent of that mean (SEE\%) for each allometric relationship are presented in Table 2 for pine and Table 3 for spruce.

Table 1. Distribution of trees sampled by dbh class.

\begin{tabular}{lcccccc}
\hline & \multicolumn{7}{c}{ DBH Classes $(\mathbf{c m})$} \\
\cline { 2 - 7 } & $\mathbf{5 - 1 5}$ & $\mathbf{1 5 - 2 5}$ & $\mathbf{2 5 - 3 5}$ & $\mathbf{3 5 - 5 0}$ & $\mathbf{5 0 - 6 5}$ & Total \\
\hline Lodgepole pine & 3 & 10 & 6 & 8 & 0 & 27 \\
White Spruce & 3 & 4 & 3 & 8 & 5 & 23 \\
\hline
\end{tabular}

Tables 2 and 3 summarize the coefficients and associated statistics of fitting each relationship independently. Depending on the need, these may be used separately to estimate a particular desired component of biomass for a tree. The weights of individual components may also be added to or substracted from other components as desired. However, as pointed out by several authors (Cunia and Briggs 1984, Chiyenda and Kozak 1984, and Reed and Green 1985 ) the summation of all individual size class and foliage estimates does not generally give the same estimate as that obtained from an equation that predicts a "total" weight. Following "Method 1"' of Cunia and Brigg (1984), additive estimates for the total crown biomass may be obtained by summing the estimates for each of the separate components (excluding live crown). As shown by Reed and Green (1985), the resulting estimate sacrifices (slightly) the precision of overall estimates obtained by fitting the total foliage relationship directly, but retains the advantage of additivity, or internal compatibility. Their study also evaluated a simultaneous estimation procedure, but concluded that differences in error variance for component equations were not large. Simultaneous models such as those of Cunia and Briggs (1984) or Reed and Green (1985) were not evaluated as part of this study.

Biomass for the larger roundwood classes (above $3.0 \mathrm{~cm}$ ) appears to be greatly affected by tree size (Johnson 1988). This results in three distinct relationships. First, if the tree $\mathrm{dbh}$ is smaller that the lower limit of the size class, for example $3.0 \mathrm{~cm}$, then there will be no biomass in the $3.0-5.0 \mathrm{~cm}$ class. Second, if the tree dbh is larger than $3.0 \mathrm{~cm}$ there is a nearly constant amount of biomass in the class until the tree reaches a size where branches are large enough to contribute biomass in that roundwood size class. The samples for both pine and spruce confirm this pattern until trees reach $25 \mathrm{~cm}$ and $28 \mathrm{~cm}$ respectively. Lastly, above these limits, trees begin to accumulate biomass in the expected pattern, and the allometric model fit the remaining data (14 and 15 trees, respectively) well.

For the larger size classes $(5.0-7.0 \mathrm{~cm}$ and $7.0-10.0 \mathrm{~cm})$ our data did not show any biomass accumulation beyond the constant level. Since some of the trees sampled here were reasonably large, maximum dbh was 48 and $63 \mathrm{~cm}$ for pine and spruce respectively, it is not clear whether branches generally will not get large enough to contribute to these classes or if trees will have to be somewhat larger to contribute to the largest roundwood size classes.

\section{Discussion}

A nonlinear model with untransformed, unweighted data was used to determine the coefficients for each equation. 
Table 2. Lodgepole pine equations for estimating the oven-dried crown weight components (kg) from diameter at breast height (DBH; cm)

\begin{tabular}{|c|c|c|c|c|c|c|c|}
\hline \multirow[b]{2}{*}{ Weight } & \multicolumn{4}{|c|}{ Allometric Coefficients (*) } & \multirow[b]{2}{*}{ SEE } & \multirow[b]{2}{*}{$Y$} & \multirow[b]{2}{*}{ SEE\% } \\
\hline & $a$ & $b$ & $n$ & $r^{2}$ & & & \\
\hline Total crown & 0.1744 & 1.8127 & 27 & 0.88 & 20.8 & 77.1 & 27.0 \\
\hline Live crown & 0.1669 & 1.7020 & 27 & 0.82 & 15.8 & 50.6 & 31.2 \\
\hline Foliage & 0.0525 & 1.6057 & 27 & 0.83 & 3.3 & 11.4 & 28.8 \\
\hline $0.0-0.5 \mathrm{~cm}$ & 0.0533 & 1.8052 & 27 & 0.88 & 6.2 & 23.0 & 27.0 \\
\hline $0.5-1.0 \mathrm{~cm}$ & 0.1369 & 1.3553 & 27 & 0.68 & 5.6 & 12.3 & 45.6 \\
\hline $1.0-3.0 \mathrm{~cm}$ & 0.1140 & 1.6047 & 27 & 0.88 & 8.9 & 23.9 & 37.3 \\
\hline \multirow[t]{2}{*}{$3.0-5.0 \mathrm{~cm}$} & \multicolumn{4}{|c|}{ use the mean value if $\mathrm{DBH}<25 \mathrm{~cm}$ : } & & \multicolumn{2}{|l|}{1.0} \\
\hline & $6.95 \times 1$ & 2.8488 & 14 & 0.60 & 11.1 & 20.0 & 55.4 \\
\hline \multirow[t]{2}{*}{$5.0-7.0 \mathrm{~cm}$} & \multicolumn{4}{|c|}{ use the mean value if $\mathrm{DBH}<35 \mathrm{~cm}$ : } & & \multicolumn{2}{|l|}{1.7} \\
\hline & $2.15 \times 1$ & 5.2771 & 8 & 0.05 & 10.9 & \multicolumn{2}{|r|}{125.5} \\
\hline $7.0-10.0 \mathrm{~cm}$ & \multicolumn{5}{|c|}{ use the mean value: } & 3.3 & \\
\hline
\end{tabular}

Where:

$(*)=$ equation in the form: WEIGHT $=a \mathrm{DBH}^{\mathrm{b}}$.

$\mathrm{SEE}=$ Standard error of the estimate $(\mathrm{kg})$.

$Y=$ Mean of the estimated and observed weight $(\mathrm{kg})$.

$\mathrm{SEE} \%=\mathrm{SEE}$ expressed as percent of the mean.

Table 3. White spruce equations for estimating the oven-dried crown weight components (kg) from diameter at breast height (DBH; cm)

\begin{tabular}{|c|c|c|c|c|c|c|c|}
\hline \multirow[b]{2}{*}{ Weight } & \multicolumn{4}{|c|}{ Allometric Coefficients (*) } & \multirow[b]{2}{*}{ SEE } & \multirow[b]{2}{*}{ Y } & \multirow[b]{2}{*}{ SEE $\%$} \\
\hline & $a$ & $b$ & $n$ & $r^{2}$ & & & \\
\hline Total crown & 0.0181 & 2.4896 & 23 & 0.88 & 60.8 & 186.4 & 32.7 \\
\hline Live crown & 0.0782 & 1.9961 & 23 & 0.88 & 34.4 & 120.0 & 28.7 \\
\hline Foliage & 0.6373 & 1.1457 & 23 & 0.69 & 14.7 & 38.5 & 38.2 \\
\hline $0.0-0.5 \mathrm{~cm}$ & 0.0869 & 1.8938 & 23 & 0.85 & 27.3 & 89.6 & 30.4 \\
\hline $0.5-1.0 \mathrm{~cm}$ & 0.0304 & 1.7481 & 23 & 0.83 & 5.7 & 18.1 & 31.3 \\
\hline $1.0-3.0 \mathrm{~cm}$ & 0.0150 & 2.1929 & 23 & 0.82 & 18.9 & 47.9 & 39.5 \\
\hline $3.0-5.0 \mathrm{~cm}$ & \multicolumn{4}{|c|}{ use the mean value if $\mathrm{DBH}<28 \mathrm{~cm}$ : } & & 0.7 & \\
\hline & \multirow{2}{*}{\multicolumn{4}{|c|}{$\begin{array}{l}7.21 \times 10^{-9} \\
\text { use the mean yalue: }\end{array}$}} & 22.8 & 38.3 & 59.4 \\
\hline $5.0-7.0 \mathrm{~cm}$ & & & & & & 2.0 & \\
\hline $7.0-10.0 \mathrm{~cm}$ & \multicolumn{4}{|c|}{ use the mean value: } & & 3.6 & \\
\hline
\end{tabular}

Where:

$(*)=$ equation in the form: WEIGHT $=a \mathrm{DBH}^{\mathrm{b}}$.

SEE $=$ Standard error of the estimate $(\mathrm{kg})$.

$Y=$ Mean of the estimated and observed weight $(\mathrm{kg})$.

$\mathrm{SEE} \%=\mathrm{SEE}$ expressed as percent of the mean.

Plots of residuals showed slightly increasing error variance with large trees. However, a weighting scheme to make the variance less unequal was not performed because a weighting technique may reduce a model's ability to be used for accurate predictive purposes for its entire dbh range (Comerford and Leaff 1982a, 1982b), and may result in only a slight reduction in the standard error of estimate (Alban and Laidly 1982). A weighted least-squares method of regression analysis has been shown to be useful for reducing heteroscedasticity (inequality of variances among samples) in forest tree biomass studies (Schreuder and Swank 1973). This procedure has a tendency to provide a better fit for the smaller, less variable sized trees and to "force" a poorer fit for larger, more variable sized trees. Comerford and Leaff (1982a, 1982b) suggested this characteristic would produce undesirable equation coefficients if accurate predictions of larger trees are also required. In studies of juvenile trees, a weighted predictive equation will generally estimate smaller tree biomass with higher accuracy than the unweighted regression equation (Smith et al. 1986); however, they predicted negative weights for unmerchantable $(<10 \mathrm{~cm})$ boles of spruce trees $>25 \mathrm{~cm}$ dbh with a weighted equation, and demonstrated that an unweighted equation provided much greater predictive accuracy of foliage and roundwood in the class 2.5 to $7.6 \mathrm{~cm}$ for trees $>18 \mathrm{~cm} \mathrm{dbh}$.
The allometric model $\left(Y=a \mathrm{dbh}^{\mathrm{b}}\right)$ was selected because each equation for total crown weight provided logical predicted values over the entire range of dbh studied and the plots of residuals and SEE were reasonable. As with all nonlinear systems, an exact significance test of each coefficient cannot be completed in the same manner as linear systems. A $\log / \log$ transformation was not completed because the statistics generated from these coefficients are unique to the linear transformed equation and cannot be applied to the nonlinear system, and (2) logarithmic bias is created during retransforming back to arithmetic units which results in a systematic under-estimation of weight (Zar 1968) unless efforts are made to correct for this error (Baskerville 1972).

For both species, the allometric model failed to provide reasonable predictions for the larger roundwood diameter classes: $3.0-5.0 \mathrm{~cm}, 5.0-7.0 \mathrm{~cm}$ and $7.0-10.0 \mathrm{~cm}$. This is perhaps because only the largest trees of each species had any branchwood in these classes. Therefore, the allometric equations could not be used to adequately predict the weight of fuels in these diameter classes. The observed weights were almost constant for the entire range of tree sizes. For smaller trees, biomass in these classes came only from small amounts of bole or stem material. The mean weight of each roundwood class should therefore be used as the best available estimate of weight. For example, the 13 lodgepole pine trees 
$<25 \mathrm{~cm}$ dbh had bole material in only the $3.0-5.0 \mathrm{~cm}$ roundwood weight class. The user should note that biomass estimates are not continuous at the break between models $(25$ and $35 \mathrm{~cm}$ ). However, for the 14 pine trees $\geq 25 \mathrm{~cm} \mathrm{dbh}$, the $3.0-5.0 \mathrm{~cm}$ roundwood class was composed of bolewood and branchwood and a separate allometric equation was used to predict the curvilinear relationship of the observed roundwood diameter class weight for these larger trees.

The trees sampled for this study are representative of the size and condition of white spruce and lodgepole pine most commonly found in the Prairie Provinces of Canada. Work by Singh (1986) found good correlations between total tree weights for pine and spruce widely sampled in Alberta, Saskatchewan and Manitoba.

While we cannot determine whether trees sampled in Alberta are similar in size and condition those growing in the other Prairie Provinces, Singh (1986) concluded that equations for total tree biomass could be used over this region. Since biomass relationships for fuel size classes have not been reported for other provinces, the relationships given here may, with some caution, be applied in other regions on an interim basis.

\section{Management Implications}

This study was initiated because of the perceived need to be able to predict residual fuel loadings prior to harvesting or other type of stand disturbances. This is why we used the fuel diameter classes recognized by the Canadian Forestry Service and most protection agencies in Canada. But the ability to predict biomass by different roundwood size classes and foliage for individual trees using only diameter at breast height has many other potential uses in forest management. First, these estimates can be used in deciding where special treatments may be required following harvesting. This would enable managers to better forecast site preparation or planting costs due to knowledge of residue loadings. Also, this information may provide the forest manager with a better knowledge of how various natural and man-caused activities affect site productivity - by influencing debris build up, decomposition, and eventually, nutrient dynamics (Abbott and Crossley 1982, Agee and Huff 1987, Weber 1987). Information on how biomass changes by size class over time can also be used in predicting future fuel levels. This can be done by incorporating biomass estimates as part of stand growth models that are based on, or predicted from, individual or average tree characteristics.

Tree diameter at breast height is a basic measurement in all forest inventories. Therefore, biomass estimates of fuel components by type and diameter classes could easily be incorporated into existing forest management inventory systems. This information if properly interpreted will greatly increase our knowledge of how forested ecosystems respond to disturbances, natural or man-caused. In addition, it will contribute to better forest management by increasing the economic efficiency of protection, planting, and site preparation activities.

\section{Acknowledgments}

This study was funded by the Protection Branch of the Alberta Forest Science. The assistance and guidance of John Benson (Director) and Terry VanNest (Fire Behavior Officer) of this Branch is greatly appreciated.

\section{References}

Abbott, D.T. and D.A. Crossley Jr. 1982. Woody litter decomposition following clear-cutting. Ecology 63: 35-42.

Agee, J.K. and M.H. Huff. 1987. Fuel succession in a western hemlock/Douglas-fir forest. Can. J. For. Res. 17: 697-704.

Alban, D.H. and P.R. Laidly. 1982. Generalized biomass equations for jack and red pine in the Lake States. Can. J. For. Res. 12: 913-921.

Baskerville, G.H. 1972. Use of logarithmic regression in estimation of plant biomass. Can. J. For. Res. 2: 49-53.

Brown, J.K. 1976. Predicting crown fuel weights for 11 Rocky Mountain conifers. Paper presented at XVIth International Congress of IUFRO, Oslo, Norway. Coll. Life Sci. Agric., Univ. Maine. 101-115.

Chiyenda, S.S. and A. Kozak. 1984. Additivity of component biomass regression equations when the underlying model is linear. Can. J. For. Res. 14: 441-446.

Comerford, N.B. and A.L. Leaff. 1982a. An evaluation of techniques for sampling forest tree nutrient content. Part 1. Sampling the crown for total nutrient content. For. Sci. 28: 471-480.

Comerford, N.B. and A.I . Leaff. 1982b. An evaluation of techniques for sampling forest tree nutrient content. Part II. Sampling for stem nutrient content. For. Sci. 28: 481-487.

Cunia, T. and R.D. Briggs. 1984. Forcing additivity of biomass tables: some empirical results. Can. J. For. Res. 14: 376-384.

Delisle, G.P. 1986. Physical components and biomass regression equations required for fuel quantification of forest stands in Jasper National Park. M.Sc. thesis, Univ. Alberta, Edmonton.

Johnson, A.F. 1988. Equations for estimating standing live white spruce and lodgepole pine fuels in Alberta. M.Sc. thesis, Univ. Alberta, Edmonton.

Johnstone, W.D. and E.B. Peterson. 1980. Above ground component weights in Alberta Populus stands. Environ. Can., Can. For. Serv., Info. Rep. NOR-X-226.

Kiil, A.D. 1967. Fuel weight tables for white spruce and lodgepole pine crowns in Alberta. Can. Dept. For. and Rural Development, For. Br., Dept. Publ. 1196.

Kiil, A.D. 1968. Weight of the fuel complex in 70-year-old lodgepole pine stands of different densities. Can. Dept. For. and Rural Development, Dept. Publ. 1228.

Moss, E.H. 1983. Flora of Alberta. University of Toronto Press, Toronto.

Reed, D.D. and E.J. Green. 1985. A method of forcing additivity of biomass tables when using nonlinear models. Can. J. For. Res. 15: 1184-1187.

Rowe, J.S. 1972. Forest Regions of Canada. Dept. Fish. and Environ., Can. For. Serv., Ottawa, Publ. 1300.

Schreuder, H.T. and W.T. Swank. 1973. Statistical considerations for a Pinus strobus L. forest. IN IUFRO biomass studies. Coll. Life Sci. Agric., Univ. Maine, Orono, ME. pp. 131-141.

Singh, T. 1986. Generalizing biomass equations for the boreal forest region of west-central Canada. For. Ecol. Manage., 17: 97-107.

Smith, C.T., M.L. McCormack, J.W. Hornbeck and C.W. Martin. 1986. Nutrient and biomass removals from red spruce - balsam fir whole tree harvest. Can. J. For. Res. 16: 381-388.

Stanek, W. and D. State. 1978. Equations predicting primary productivity (biomass) of trees, shrubs, and lesser vegetation based on current literature. Environ. Can., For. Serv., Info. Rep. BC-X-183.

Stocks, B.J. 1980. Black spruce crown fuel weights in northern Ontario. Can. J. For. Res. 10: 498-501.

Strong, W.L. and K.R. Leggat. 1981. Ecoregions of Alberta. Alta. Energy Nat. Resour., Resour. Evalu. Plann. Div., Edmonton, AB. ENR Tech. Rep. T/4.

Van Wagner, C.E. 1982. Practical aspects of the line intersect method. Can. For. Serv., Petawawa For. Exp. Stn. Info. Rep. PI-X-12.

Weber, M.G. 1987. Decomposition, litter fall, and forest floor nutrient dynamics in relation to fire in eastern Ontario Jack pine ecosystem. Can. J. For. Res. 17: 1496-1506.

Woodard, P.M., and G.P. Delisle. 1987. Biomass regression equations for common tree seedlings and shrubs in Jasper National Park, Alberta. Univ. Alberta Forestry Note 1. 10 pp.

Zar, J.H. 1968. Calculation and miscalculation of the allometric equation as a model in biological data. BioSci. 18: 1118-1120. 